ARTIKEL PENELITIAN

\title{
PENGARUH PIJAT BAYI TERHADAP BERAT BADAN DAN LAMA TIDUR BAYI
}

\author{
Sawitry $^{1)}$, TjahjonoKuntjoro ${ }^{2)}$, Ida Ariyanti ${ }^{3)}$ \\ 1,2Epidemiologi Konsentrasi Sains Terapan Kesehatan, Universitas Diponegoro, \\ Semarang \\ ${ }^{3}$ Profesi Kebidanan, Poltekkes Kemenkes ,Semarang \\ Email :weet.ibnu@yahoo.com
}

\begin{abstract}
Baby age 1-3 months in Sendang Mulyo have a problems. The baby's weight is difficult to rise and fuss before going to bed, reduce the quality of sleep and impact on growth and development, babymassage can be one of alternative sollution for it. Aim of research knows the differences and effects of baby massage to increase of body weight and duration of sleep. Research method Quasi Experiment with Pre and Post test with control group design, data analysis using Dependent and Independent $\mathrm{T}$ test. The results There was an increase the body weight and durration of sleep following intervention in the treatment group. The effect of baby massage to increase the body weight P Value 0.002, and the duration of sleep P Value 0.007. Conclusions. There were differences in body weight and duration of sleep in both groups, and there was the effect of infant massage to increase body weight and sleep duration for infants aged 1-3 months.
\end{abstract}

Keywords: infant massage, weight and durration of sleep

\begin{abstract}
Abstrak
Bayi usia 1-3 bulan di wilayah Sendang Mulyo memiliki permasalahan yaitu berat badan bayi sulit naik dan rewel sebelum tidur sehingga mengurangi kualitas tidur dan berdampak pada pertumbuhan dan perkembangan, pemijatan pada bayi dapat menjadi alternatif untuk mengatasi permasalahan tersebut. Tujuan mengetahui pengaruh pijat bayi terhadap peningkatan berat badan dan lama tidur bayi usia 1-3 bulan. Metode Quasi Experiment dengan Pre danPost test with control group design, analisa data menggunakan Dependent dan Independent $\mathrm{T}$ test. Hasil Peningkatan berat badan dan lama tidur pada kelompok eksperimen lebih baik. Ada pengaruh pijat bayi terhadap peningkatan berat badan dengan $\mathrm{P}$ Value 0,002 , dan lama tidur bayi dengan $\mathrm{P}$ Value 0,007.Simpulan ada perbedaan berat badan serta lama tidur pada kedua kelompok, dan ada pengaruh pijat bayi terhadap peningkatan berat badan serta lama tidur pada bayi usia 1-3 bulan.
\end{abstract}

Keywords : pijat bayi, berat badan dan lama tidur

\section{PENDAHULUAN}

Bayi mengenali seseorang melalui sentuhan dan suara, pijat bayi merupakan salah satu sentuhan yang dapat memberikan banyak manfaat diantaranya rasa aman, nyaman, serta dapat menstimulasi pertumbuhan serta perkembangan bayi, pijatan pertama yang dirasakan bayi adalah saat proses kelahirannya yaitu saat bayi melalui jalan lahir. Pijat merupakan salah satu teknik pengobatan penting yang sudah dikenal sejak lama (Utami Roesli, 2009). 
Pijatan bayi merupakan salah satu cara yang menyenangkan untuk menghilangkan ketegangan dan kerewelannya, karena pijatan lembut akan membantu mengendurkan ototototnya sehingga ia menjadi tenang dan tertidur (Asti,2005). Penelitian klinis menunjukkan bahwa sentuhan sayang dan pijatan membantu bayi tumbuh lebih kuat dan tidur lebih nyenyak, serta bermanfaat untuk mengurangi masalah tidur (Dewi A,2005).

Di wilayah Sendang Mulyo ada 32 bayi yang berusia 1-3 bulan, beberapa bayi mengalami kenaikan berat badan yang lambat, bahkan ada yang tidak naik dalam 2 bulan terakhir, 4 ibu belum mengetahui manfaat pijat bayi, bayi juga rewel menjelang tidur, sering terbangun saat tidur, serta mengalami waktu tidur yang tidak teratur. Rumusan Masalah "Adakah pengaruh pijat bayi terhadap peningkatan berat badan, dan Lama tidur Pada Bayi Umur 1-3 Bulan Di Wilayah Sendang Mulyo ?’. Tujuan Penelitian mengetahui pengaruh pijat bayi terhadap peningkatan berat badan dan lama tidur bayi usia 1-3 bulan di Wilayah Sendang Mulyo.

\section{METODE PENELITIAN}

Jenis penelitian adalah Quasi Experiment dengan Desain Pre dan Post test with control group design, sampel pada penelitian ini adalah bayi usia 1-3 bulan dengan intervensi yang dilakukan adalah pemijatan 2 kali/ minggu selama 4 minggu, kemudian dianalisa pengaruh pemijatan yang dilakukan tersebut terhadap berat badan serta lama tidur bayi, data kelompok berpasangan dianalisa menggunakan Dependent $T$ Test dan Wilcoxon, sedangkan data kelompok tidak berpasangan dianalisa menggunakan Independent T test dan Mann Whitney.

\section{HASIL DAN PEMBAHASAN}

\section{Pengaruh Pijat Bayi terhadap peningkatan berat badan bayi usia 1-3 bulan di wilayah Sendang Mulyo}

Tabel 1 Perbedaan Berat Badan Bayi usia 1-3 bulan sebelum dan sesudah dilakukan pijat bayi di Wilayah Sendang Mulyo 
Tabel 1 menunjukkan bahwa rata -rata berat badan bayi usia 1-3 bulan pada kelompok eksperimen sebelum adalah 4254 dan sesudah adalah 5101,87 Perbedaan berat badan sebelum dengan sesudah pada kelompok eksperimen berdasarkan uji statistik dengan menggunakan Dependent $\mathrm{T}$ Test, hasilnya P Value $0,000<0,05, \quad$ sehingga ada perbedaan berat badan sebelum dan sesudah pada kelompok eksperimen.

Rata -rata berat badan bayi usia 1-3 bulan pada kelompok kontrol sebelum adalah 4796,67 dan sesudah adalah 5491. Perbedaan berat badan sebelum dengan sesudah pada kelompok kontrol berdasarkan uji statistik dengan menggunakan Dependent T Test, hasilnya P Value $0,000<0,05, \quad$ sehingga ada perbedaan berat badan sebelum dan sesudah pada kelompok kontrol.

Pengaruh Pijat bayi terhadap peningkatan berat badan pada kelompok eksperimen dan kelompok kontrol berdasarkan uji statistik dengan menggunakan Independent $T$ Test, hasilnya P Value 0,002, sehingga $<0,05$, dapat disimpulkan

\begin{tabular}{cccc}
\hline Klp & Eksperimen & Kontrol & $\begin{array}{c}\text { P } \\
\text { value }\end{array}$ \\
\cline { 1 - 3 } Sebelum & 4254 & 4796,67 & 0,002 \\
\hline Sesudah & 5101,87 & 5491 & 0,02 \\
\hline P Value & 0,000 & 0,000 & \\
\hline
\end{tabular}

bahwa ada pengaruh pijat bayi terhadap peningkatan berat badan pada bayi usia 1-3 bulan

Ibu bayi pada kelompok eksperimen menyatakan bahwa setelah dipijat bayinya ada peningkatan frekuensi menyusu, dan beberapa ibu juga mengatakan jumlah ASI nya meningkat, hal ini juga menunjang peningkatan berat badan bayi, apalagi bayi pada usia ini masih jarang bergerak sehingga asupan nutrisi yang masuk terfokus untuk meningkatkan pertumbuhannya, sedangkan pada kelompok kontrol menyatakan bahwa volume ASI nya bertambah dan frekuensi menyusu bayinya juga meningkat, adanya peningkatan volume ASI dan frekuensi menyusu ini dapat menyebabkan peningkatan berat badan bayi.

Bayi yang dipijat mengalami peningkatan aktivitas nervus vagus (saraf otak ke-10) yang akan menyebabkan bayi cepat merasa 


\begin{tabular}{lccc}
\hline \multicolumn{1}{c}{ Klp } & $\begin{array}{c}\text { Eksperime } \\
\mathrm{n}\end{array}$ & Kontrol & $\begin{array}{c}\mathrm{P} \\
\text { value }\end{array}$ \\
\cline { 1 - 3 } Sebelum & 13,73 & 13,33 & \multirow{2}{*}{0,007} \\
\cline { 1 - 3 } Sesudah & 16,93 & 15,53 & \\
\cline { 1 - 3 } P Value & 0,001 & 0,001 & \\
\hline lapar & sehingga & \multicolumn{2}{c}{ frekuensi }
\end{tabular}

Tabel 2 Perbedaan Lama Tidur Bayi usia 1-3 bulan sebelum dan sesudah dilakukan pijat bayi di Wilayah Sendang Mulyo

Tabel 2 menunjukkan bahwa rata menyusunya meningkat, selain itu adanya peningkatan kadar enzim penyerapan gastrin dan insulin, dengan demikian, penyerapan makanan akan menjadi lebih baik (Prasetyono, 2013)

Penelitian ini sejalan dengan penelitian Maria Silvia dengan hasil ada kenaikan berat badan bayi ( $\mathrm{P}$ 0,046) yang dipijat setiap harinya selama 10-15 menit(Maria, 2010). Penelitian yang sejenis juga menunjukkan hasil yang sama yaitu penelitian oleh Serrano dengan hasil p 0,036 sehingga terdapat perbedaan kenaikan berat badan antara kelompok kontrol dengan kelompok intervensi setelah dilakukan pemijatan.(Serrano,2010)

\section{Pengaruh pijat bayi terhadap} lama tidur bayi usia 1-3 bulan di wilayah Sendang Mulyo 
mengganti popok/ celana jika basah, kemudian bayi akan tertidur kembali

Berdasarkan uji statistik dengan menggunakan uji Mann Whitney,hasilnya P Value 0,007, sehingga $<0,05$, dapat disimpulkan bahwa ada pengaruh pijat bayi terhadap lama tidur pada bayi usia 13 bulan.

Pada bayi yang dipijat $2 \mathrm{x}$ seminggu memiliki kualitas tidur yang lebih baik dari pada bayi yang tidak dipijat, kualitas tidur bisa dilihat dari lama tidurnya yang semakin meningkat, frekuensi bangun selama periode tidur semakin berkurang, saat menjelang tidur bayi tidak rewel dan bayi juga jarang terbangun di malam hari.

Kelompok Bayi yang tidak dilakukan pemijatan, juga memiliki lama tidur yang berubah, seiring bertambahnya usia bayi serta faktor lainnya misalkan lingkungan yang aman dan nyaman, bayi sebelum tidur menyusu dengan adekuat, sehingga tertidur karena kenyang, namun pada kelompok ini beberapa bayi masih memiliki frekuensi tidur yang tidak teratur, sering terbangun dan rewel saat menjelang tidur.
Pijat bayi merupakan salah satu cara untuk mengatasi masalah tidur pada bayi. Pijat bayi merupakan salah satu cara yang menyenangkan untuk menghilangkan ketegangan dan perasaan gelisah terutama pada bayi. Pijatan lembut akan membantu mengendurkan otot-ototnya sehingga bayi menjadi tenang dan tidurnya nyenyak. (Utami Roesli, 2009)

Penelitian ini juga didukung oleh penelitian Hae-Kyung Lee,Ph.D,RN, yang meneliti tentang The Effect of Infant Massage on wheigt gain, Physiological and Behavioral Responses in Prematur infants, hasilnya ada kenaikan berat badan yang signifikan terjadi pada kelompok eksperimen serta ada perubahan pada aktifitas motorik bayi serta respon bayi prematur yang dipijat meningkat seperti saat menangis dan tidur.( Hae-Kyung L, 2006)

Penelitian ini sejalan dengan penelitian Julia Leonard yang meneliti tentang Exploring Neonatal Touch, hasilnya pemijatan pada bayi prematur yang ada di NICU memberikan banyak solusi bagi pertumbuhan dan perkembangan, 
salah satunya bayi tidur lebih nyenyak.( Julia L, 2008)

\section{SIMPULAN}

Berdasarkan tujuan penelitian

dapat ditarik simpulan sebagai

berikut :

1. Ada perbedaan berat badan sebelum dan sesudah pemijatan pada kelompok eksperimen dan kelompok kontrol

2. Ada pengaruh pijat bayi terhadap peningkatan berat badan bayi usia 1-3 bulan pada kelompok eksperimen maupun kelompok kontrol

3. Ada perbedaan lama tidur pada kelompok eksperimen dan kontrol

\section{UCAPAN TERIMA KASIH}

Peneliti mengucapkan rasa syukur kepada Allah SWT yang telah melimpahkan rahmat serta karuniaNya, serta tak lupa pula ucapan terima kasih kepada kedua orang tua, suami, ananda Fakhri tercinta serta teman teman yang telah memberikan dukungan kepada peneliti sehingga dapat menyelesaikan studi di Magister
4. Ada pengaruh pijat bayi terhadap lama tidur bayi usia 13 bulan pada kelompok eksperimen maupun kelompok kontrol

\section{Saran}

1. Bagi ibu yang memiliki bayi dan balita dapat secara mandiri melakukan stimulasi tumbuh kembang melalui pemijatan, yang membawa banyak manfaat bagi ibu,bayi dan balita.

2. Bagi peneliti selanjutnya dapat mengembangkan penelitian dengan tema yang sama, namun lebih memperhatikan variabel confounding

Epidemiologi Sains Terapan Kesehatan Universitas Diponegoro Semarang

\section{DAFTAR PUSTAKA}

Roesli, Utami. 2009. Pedoman Pijat Bayi. Jakarta: PT Trubus Agriwidya

Rahayu, Asti. 2005. Pedoman Merawat Bayi. Jakarta : Erlangga 
Astuti, Dewi. 2005. Panduan Praktis

Memijat Buah Hati Anda.

Yogyakarta : Nusa Pressindo

Prasetyono, D.S.2013.Buku Pintar

Pijat Bayi.Jogjakarta: Buku

Biru

Silvia Maria, 2010, Teaching Chilean Mothers To Massage Full Term Infant, https://scholar.google.co.id/s cholar?

$q=$ Teaching + Chilean + Mothe

$r+$ To + Massage + Full + Therm

+ Infant $\% 2 C+$ Height

$\% 2=\& h l=e n \& a s \_s d t=0 \% 2 C$

5

Serrano, 2010, Messaging newborn may help weight gain up 2 months age, https://scholar.google.co.id/s cholar?

$q=$ Messaging + Newborn + hel $p+$ weight + Gain + up +2 month + age $\% 2 \mathrm{C}+\mathrm{Height}$ $\% 2=\& h l=e n \& a s \_s d t=0 \% 2 C$ 5
Hae-Kyung L, 2006, The Effects of Infant Massage on Weight,Height, and MotherInfant Interaction, Journal of Korean Academy of Nursing Vol. 36, No. 8 dalam https://scholar.google.co.id/ scholar? $q=$ The + Effects + of + Infant + Massage+on + Weight $\% 2 C+$ Height $\% 2 C+$ and + MotherInfant + Interaction\&btn $G=$ $\& h l=e n \& a s \_s d t=0 \% 2 C 5$

Julia L, 2008, Exploring Neonatal Touch, The Wesleyan Journal of Psychology Vol.3, dalam https://scholar.google.co.id/ scholar? $q=$ Exploring + Neonatal + To $u c h \& b \operatorname{tn} G=\& h l=e n \& a s \_s d t$ $=0 \% 2 C 5$ 
